\title{
LCMS/MS analysis and evaluation of anti-inflammatory and antioxidant activities of the polyphenol fraction of Litsea quinqueflora (Dennst.) Suresh
}

\author{
Sumin Mary Jose \& Anilkumar $\mathrm{M}^{*}$ \\ Department of Botany, Union Christian College, Aluva 683 102, Kerala, India \\ *Email: drmakumar@gmail.com
}

\section{ARTICLE HISTORY}

Received: 01 May 2021

Accepted: 13 July 2021

Available online: 21 August 2021

\section{KEYWORDS}

ABTS

DPPH

Free radical scavenging

HPTLC

LCMS/MS

Protein denaturation

\begin{abstract}
The main aim of the work was to scientifically prove the anti-inflammatory property of the polyphenol-rich fraction of hydro-alcoholic leaf extract of Litsea quinqueflora (Dennst.) Suresh by protein denaturation and free radical scavenging activity. The polyphenol-rich fraction of hydroalcoholic leaf extract was obtained via acid-alkali hydrolysis, followed by fractionation with chloroform and ethyl acetate. HPTLC profiling of the finally obtained ethyl acetate fraction and consequent derivatisation with aluminium chloride revealed the presence of flavonoids in a more purified form. LCMS/MS analysis tentatively identified the presence of bioactive polyphenolic compounds such as gallocatechin, sinapic acid, pinocembrin, paeonol and umbelliferone in the separated fraction. The polyphenol-rich fraction of hydro-alcoholic extract of leaves showed anti-denaturing activity in heatinduced bovine serum albumin denaturation with an $\mathrm{IC}_{50}$ value of $23.59 \mu \mathrm{g} / \mathrm{ml}$ and was statistically significant at $0.1 \%$ level. The antioxidant property of the polyphenol-rich fraction determined by its free radical scavenging ability against DPPH and ABTS showed $I C_{50}$ values 122.98 and $135.44 \mu \mathrm{g} / \mathrm{ml}$ respectively and was also statistically significant at $0.1 \%$ level. Hence, the traditional use of Litsea quinqueflora as an anti-inflammatory agent can be attributed to the presence of polyphenols.
\end{abstract}

\section{Introduction}

Plant-derived medicines attracted the attention of researchers due to the presence of different phytochemicals having a multitude of health benefits to humans (1). Among these phytochemicals, polyphenols are of much importance owing to their specific biological properties. They are the organic foods produced by plants as secondary metabolites. Polyphenols are involved in the physiological and other diverse functions such as lignification, growth, predator resistance etc. (2). These inevitable plant products play an important role in human health as they regulate metabolism, weight, cell proliferation and chronic diseases (3). Biological properties such as anti-inflammatory, immunomodulatory, antioxidant, cardioprotective and anticancer activities can be attributed to polyphenols (4). The diverse structure of phenolic compounds influences the anti-inflammatory activity of a drug. Even though a variety of nonsteroidal anti-inflammatory drugs (NSAIDs) are available, natural phenolic compounds are also equally good and can inhibit the pro-inflammatory mediators such as interleukins, cyclooxygenase, lipoxygenase, nuclear factors etc. Traditional healers could identify the efficacy of plant-derived compounds, and they used them widely even before the advent of allopathy drugs (5).

The genus Litsea belongs to the family Lauraceae, which possess various pharmacological properties and have been used in traditional medicines to treat influenza, stomachaches, inflammatory diseases, bruises, insect bites etc. (6). Phytochemical analysis of different Litsea species identified flavonoids and terpenoids as their major constituents (7). Flavonoids obtained from different Litsea species such as Litsea cubeba Pers., Litsea glutinosa (Loureiro) Robinson and Litsea coreana $\mathrm{H}$. Lev. act as anti-inflammatory and antioxidant compounds and inhibited different inflammatory pathways (8). Flavonoids like pinocembrin chalcone and kaempferol 3,4 '-di-O-Lrhamnopyranoside were isolated from the leaves of Litsea fruticosa (Hemsl.) Gamble through column chromatography (9). Leaves of Litsea quinqueflora (Dennst.) Suresh was selected as the test material in this study as its leaf paste has been frequently used by the local healers of Kerala as an anti-inflammatory drug. The anti-inflammatory property of crude methanolic extract of $L$. quinqueflora leaves was 
reported using the HRBC membrane stabilisation method under induced hypotonic conditions and preliminary screening revealed the presence of different biologically active phytochemicals (10). Different leaf extracts of $L$. quinqueflora possessed flavonoids and phenols and exhibited antioxidant properties also (11). All these studies used crude extracts of leaves, but a hydro-alcoholic solvent system was reported suitable for the extraction of polyphenol compounds (12). Hence, the present investigation was aimed to isolate, characterise and evaluate the anti-inflammatory and antioxidant properties of polyphenolic fraction (PLE) of the hydro-alcoholic leaf extract of L. quinqueflora. A more purified fraction of the hydroethanolic leaf extract was obtained via acid-alkali hydrolysis and fractionation using chloroform and ethyl acetate. This purified extract was then subjected to HPTLC followed by LCMS/MS analysis to get a clear picture of its phytochemical background.

\section{Materials and Methods}

\section{Collection of plant and processing}

Leaves of Litsea quinqueflora (Dennst.) Suresh was obtained from the Kurianad area of Kottayam district, Kerala, India. The flowering and fruiting twig of the plant is presented in Fig 1. The plant specimen was identified and authenticated by Dr Sujanapal. P, Kerala Forest Research Institute (KFRI), Kerala, India. The voucher specimen was deposited in the National Herbarium of KFRI (Accession No. 13057). Leaves from female plants were separated from twigs and washed thoroughly in water, and kept for shade drying. It was then powdered and used for further studies.

\section{Isolation of polyphenols}

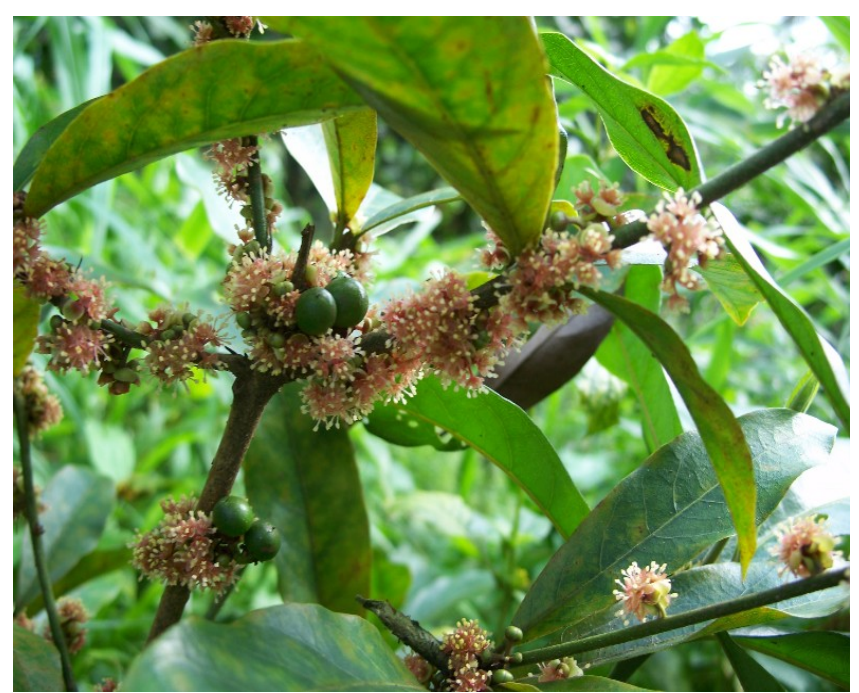

Fig. 1. Flowering and fruiting twig of Litsea quinqueflora (Dennst.) Suresh.

Extraction of polyphenol was done by the acid-alkali hydrolysis method (13), followed by fractionation with chloroform and ethyl acetate $(14,15)$. Powdered plant material $(10 \mathrm{gm})$ was added to $100 \mathrm{ml} 80 \%$ ethanol followed by agitation at $200 \mathrm{rpm}$ for $5 \mathrm{hrs}$ at room temperature in a shaking incubator (211DS, Labnet, NJ, USA). The filtrate thus obtained was concentrated at $40{ }^{\circ} \mathrm{C}$ in a rotary evaporator (Hei-VAP Core, Heidolph, Germany). The $\mathrm{pH}$ changes were made by adding $\mathrm{NaOH}$ and $\mathrm{HCl}$. The chloroform layer was separated and discarded. Ethyl acetate fraction of the acidified extract was collected and concentrated at $110 \mathrm{rpm}$. The concentrated fraction was blended at $120 \mathrm{rpm}$ for $5 \mathrm{hrs}$ with $50 \mathrm{ml} \mathrm{NaOH}$. This alkaline fraction was acidified with $\mathrm{HCl}$, and the separated ethyl acetate layer was concentrated to dryness (13).

\section{HPTLC fingerprint profiling}

High-Performance Thin Layer Chromatography (HPTLC) was performed with $5 \times 10 \mathrm{~cm}$ aluminium plates pre-coated with silica gel $\mathrm{F}_{254}$ (Merck, Germany). The polyphenol sample thus isolated was dissolved in methanol, and $2 \mu \mathrm{l}$ was spotted to the pre-activated plate using automatic TLC applicator Linomat-V with continuous $\mathrm{N}_{2}$ flow (CAMAG, Switzerland). The plate was placed in the twin glass chamber for development in the mobile phase consisting of toluene, ethyl acetate and methanol in the ratio 7:3:1. Visualisation of the oven-dried plate was done in CAMAG TLC visualiser under UV $254 \mathrm{~nm}$, $366 \mathrm{~nm}$ and visible light. HPTLC profiles were obtained after derivatisation using $\mathrm{AlCl}_{3}$ (1 \% ethanolic solution of aluminium chloride) $(16,17)$. Densitometric scanning of these plates was carried out in CAMAG TLC scanner III using a deuterium lamp with Camag WIN CATS software.

\section{LC-ESI-MS/MS analysis}

Liquid chromatography-mass spectroscopic analysis (18) was performed with Agilent 6520 accurate mass Quadrupole - Time of Flight (Q-TOF-LC/MS) attached with Agilent LC 1200 outfitted with Extend C-18 column of $1.8 \mu \mathrm{m}, 2.1 \times 50 \mathrm{~mm}$ size. Gradient elution was carried out with methanol (A) and $0.1 \%$ acetic acid (B) in the ratio of 70:30 at a constant flow rate of $0.8 \mathrm{ml} / \mathrm{min}$. LC-ESI-MS analysis was conducted in ESI negative mode. The optimisation for MS conditions was: drying gas (nitrogen) flow $5 \mathrm{~L} / \mathrm{min}$; nebuliser pressure 40 psig; drying gas temperature $325^{\circ} \mathrm{C}$; capillary voltage $3000 \mathrm{~V}$; fragmentor volt $125 \mathrm{~V}$; Oct RF Vpp 750 V. Collision voltage of 4 V/100 Dalton with an offset of $6 \mathrm{~V}$ was used for the Collision Induced Dissociation (CID) in the mass fragmentation.

\section{Anti-inflammatory assay: Inhibition of protein denaturation}

Inhibition of protein denaturation was done as per the method of Mizushima and Kobayashi (19). The reaction mixture ( $\mathrm{pH}$ 6.3) contained $0.45 \mathrm{ml}$ of $1 \%$ aqueous solution of bovine serum albumin (BSA) with $0.05 \mathrm{ml}$ of leaf extracts $(62.5,125,250,500$ $\mu \mathrm{g} / \mathrm{ml})$. The reaction mixture was incubated at $37^{\circ} \mathrm{C}$ for $20 \mathrm{~min}$, and later the temperature was raised to $57{ }^{\circ} \mathrm{C}$ for $3 \mathrm{~min}$. It was then allowed to cool at room temperature. Then added $2.5 \mathrm{ml}$ of phosphatebuffered saline (PBS) of $\mathrm{pH} 6.3$ and measured the optical density (OD) at $660 \mathrm{~nm}$ using UV-Vis spectrometer (Shimadzu - UV 1800) with PBS as blank. Diclofenac sodium was used as the standard anti-inflammatory drug. Test control was mixed with distilled water instead of extract, and in product control, distilled water was added instead of BSA.

The percentage of inhibition (20) was calculated by the formula, 


$$
100-\left[\frac{\text { OD of test solution }- \text { OD of product control }}{\text { OD of test control }}\right] \times 100
$$

\section{Antioxidant assay}

The reducing power of PLE against free radicals was analysed with DPPH (1, 1 diphenyl-2-picryl hydrazyl) radical scavenging assay and ABTS [2, 2'-azino-bis (3ethylbenzothiazolin-6-sulfonic acid)].

\section{DPPH radical scavenging assay}

Evaluation of radical scavenging activity of PLE against DPPH was done with $0.1 \mathrm{mmol} / \mathrm{L}$ of $\mathrm{DPPH}$ based on the standard method (21). The reaction was done with $1 \mathrm{ml} \mathrm{DPPH}$, and $0.5 \mathrm{ml}$ of PLE of various concentrations (12.5, 25, 50 and $100 \mu \mathrm{g} / \mathrm{ml}$ ) and test control was taken without sample. The reaction solution was finally adjusted to $3 \mathrm{ml}$ by adding ethanol and incubated in the dark for $20 \mathrm{~min}$. Ascorbic acid was used as the standard drug to compare with the test, and absorbance was measured at $517 \mathrm{~nm}$.

\section{ABTS radical scavenging assay}

This decolourisation assay was done according to the method of Re et al. (22). The reaction solution was prepared by mixing $7 \mathrm{mM}$ ABTS and $2.45 \mathrm{mM}$ Potassium persulfate (1:1) in distilled water. It was then incubated in the dark at room temperature for 12-16 hrs. The prepared ABTS solution was diluted with methanol to obtain an absorbance of 0.700 at $734 \mathrm{~nm}$. Test solution $(100 \mu \mathrm{l})$ was prepared with different concentrations of PLE (12.5, 25, 50, 100, 200 $\mu \mathrm{g} / \mathrm{ml}$ ) and was added to $900 \mu \mathrm{l}$ of ABTS solution and incubated at room temperature for $1 \mathrm{~min}$. The absorbance was measured at $734 \mathrm{~nm}$, where methanol served as blank and ascorbic acid as standard.

The antioxidant activity was calculated using the formula,

$$
\left[\frac{\text { Absorbance of control solution-Absorbance of test }}{\text { Absorbance of control solution }}\right] \times 100
$$

\section{Statistical analysis}

The anti-inflammatory and antioxidant assays were performed in triplicates, and results were expressed in mean with standard deviation. $\mathrm{IC}_{50}$ values were calculated using Microsoft Excel 2013. The inhibitory percentages obtained with each concentration of each assay were statistically analysed through oneway analysis of variance (ANOVA) followed by post hoc Tukey test using IBM SPSS statistics $25(23,24)$.

\section{Results and Discussion}

The plant phenols exist mainly in conjugated forms, either as esters or as glycosides (25). Phenolic compounds, especially flavonoids, are mainly extracted through alcoholic solvents, and further $\mathrm{pH}$ changes of the extracts lead to the frequent hydrolysis of flavonoids and increased the separation of the maximum amount of phenolic constituents (25). Acid and alkaline hydrolysis of the extract leads to the separation or glycosylation of phenolic glycosides and resulted in the formation of aglycones. The easy absorption and enhanced solubility of phenolic aglycones than bound forms were evaluated and proved in earlier studies in Ginkgo biloba $\mathrm{L}$. flavonoids in rat plasma (26). Methods of extraction of polyphenols included isolation of aglycones from different polyphenol compounds such as isoflavones, flavanones, anthocyanins etc. (27). Different hydrolytic methods like heating enabled to break down glycosides and separated aglycones from soybeans (28) and grapefruit (29).

\section{Isolation of polyphenols and HPTLC fingerprint profiling}

The hydroethanolic filtrate of $L$. quinqueflora leaves after acid-alkali hydrolysis and fractionation with chloroform and ethyl acetate yielded $0.04 \%$ polyphenol fraction of extract from leaf powder. The maximum separation of polyphenols was obtained with the mobile phase toluene, ethyl acetate and methanol in the ratio 7:3:1. The $\mathrm{Rf}$ values ranged from $0.01-0.92$. The bands prominent at $254 \mathrm{~nm}$ were not so prominent at $366 \mathrm{~nm}$. But no bands were obtained under visible light. There were four main peaks obtained under $366 \mathrm{~nm}$. Densitometry estimation revealed that $\mathrm{Rf}$ value 0.09 was predominant with $42 \%$ area followed by $\mathrm{Rf}$ values 0.17 and 0.33 . HPTLC profiling with densitometric estimation and derivatisation is shown in Fig. 2 and peak values in Table 1. Derivatisation with aluminium chloride showed prominent yellow fluorescence between $\mathrm{Rf}$ values 0.1 and 0.2 , indicating flavonoids in the extract.

HPTLC profiling of flavonoids of stem extract of Cissus latifolia Lam. was done with the mobile phase Toluene: ethyl acetate: formic acid (7:3:0.1), where eight separation spots were noticed (30), and this can be compared with the five separation spots of PLE. HPTLC profiling is quality control of herbal drugs. The HPTLC analysis of hexane, ethyl acetate and ethanol extracts of heartwood and small branches of Litsea chinensis Lam. produced a similar banding pattern in which ethanol extract showed clearer bands than others (31). The HPTLC fingerprint profiling of flavonoids of leaf and root extracts of Hypochaeris radicata L. (32), fruit extracts of Carissa bispinosa (L.) Desf. ex Brenan, Ficus sycomorus L. and Grewia bicolor Juss. (33) used aluminium chloride as a spraying reagent in the derivatisation of plates and reported the presence of flavonoids with the indication of yellow fluorescence. Hence, it can be assumed that the yellow colouration on the HPTLC plate of PLE indicates the presence of flavonoids in a more purified form. The yellow colour fluorescence obtained after derivatisation with spraying reagent can be due to the reaction between aluminium ion, $\mathrm{Al}$ (III), and carbonyl and hydroxyl groups of flavones and flavonols of PLE (34).

\section{LC-ESI-MS/MS analysis}

Liquid chromatography of PLE was carried out with mass analysis in negative polarity mode. This study revealed the presence of different polyphenolic compounds identified with $\mathrm{m} / \mathrm{z}$ value and fragmentation pattern. Mass bank.eu data was used for the identification of compounds with different ions having different $\mathrm{m} / \mathrm{z}$. Total ion chromatogram (TIC) was extracted to obtain the base peak chromatogram (BPC) of separated molecular ions. The ion with $\mathrm{m} / \mathrm{z} 305.0395$ [M-H] $]^{-}$yielded a fragment of $\mathrm{ms} / \mathrm{ms}$ at $\mathrm{m} / \mathrm{z} 131.06,199.13,201.1,215.1,245.08$, 


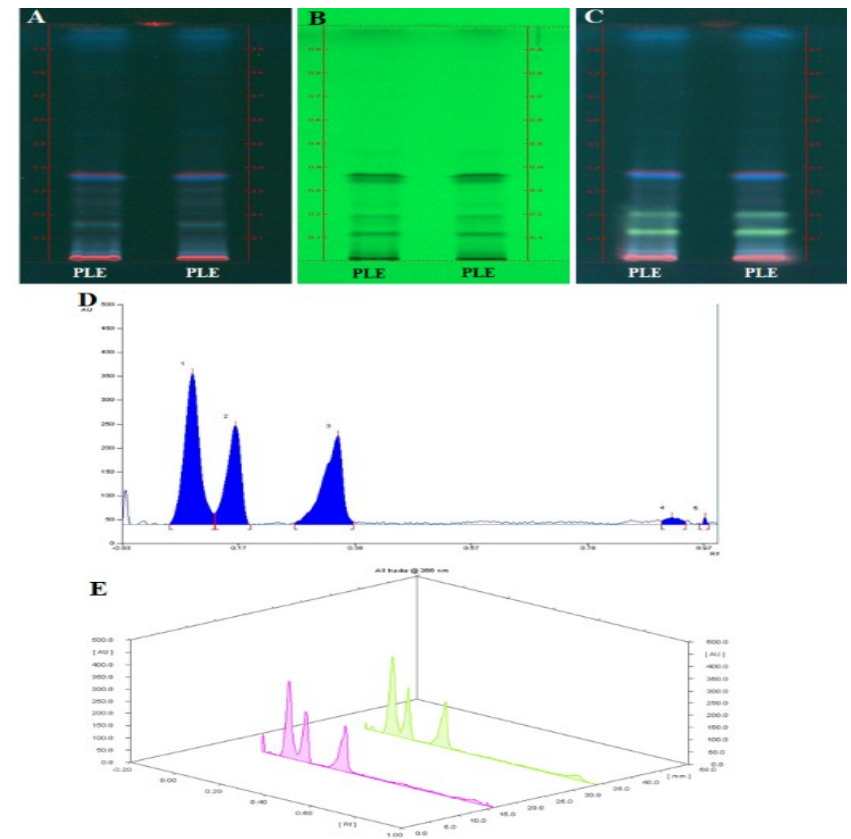

Fig. 2. HPTLC profile of PLE (A) Before derivatisation at UV $366 \mathrm{~nm}$, (B) Before derivatisation at UV $254 \mathrm{~nm}$, (C) After derivatisation at UV $366 \mathrm{~nm}$, (D) Peak densitogram of PLE, (E) Three-dimensional representation of chromatogram.

Table 1. Peak list and Rf values of polyphenol fraction (PLE) of Litsea quinqueflora

\begin{tabular}{ccclll}
\hline Peak & $\begin{array}{c}\text { Max } \\
\text { Position } \\
\text { (Rf) }\end{array}$ & $\begin{array}{c}\text { Max } \\
\text { Height } \\
\text { (AU) }\end{array}$ & Max \% & Area (AU) & Area \% \\
\hline 1 & 0.01 & 16.1 & 2.12 & 141.0 & 0.77 \\
\hline 2 & 0.09 & 322.8 & $42.57 \%$ & 7742.4 & 42.34 \\
\hline 3 & 0.17 & 210.7 & 27.78 & 4556.4 & 24.92 \\
\hline 4 & 0.33 & 189.6 & 25.00 & 5043.8 & 27.58 \\
\hline 5 & 0.92 & 19.2 & 2.53 & 801.1 & 4.38 \\
\hline
\end{tabular}

which was tentatively identified as gallocatechin. Fragments obtained from $\mathrm{m} / \mathrm{z}$ 135, 149.04, 179.12 and 223.06 point to the presence of sinapic acid with $\mathrm{m} / \mathrm{z}$ 223.034. The presence of pinocembrin, a polyphenol, was identified by the ion with $\mathrm{m} / \mathrm{z} 255.25$ and corresponding fragments with $\mathrm{m} / \mathrm{z} 106,115,125$ and 255. The mass fragment pattern of the ion with $\mathrm{m} / \mathrm{z}$ 165 showed m/z 119, 121 and 122 and denoted the polyphenol paeonol. The ion with $\mathrm{m} / \mathrm{z}$ at 161 showed a mass fragment pattern of $\mathrm{m} / \mathrm{z} 117$ and 161 which can be recognised as umbelliferone (7- hydroxyl coumarin). The mass value and fragments of identified compounds are shown in Table 2 and the spectrum of each compound is displayed in Fig. 3.

The LCMS analysis revealed the presence of different polyphenolic compounds, which were considered natural anti-inflammatory agents. The ion with $\mathrm{m} / \mathrm{z} \quad 305.0395 \quad[\mathrm{M}-\mathrm{H}]^{-}$was assumed as gallocatechin, a flavonol categorised under the flavonoid class of polyphenols (35). LC-ESI-MS/MS analysis of phenolics of different plants belonging to the family Lamiaceae reported the same $\mathrm{m} / \mathrm{z}$ value for gallocatechin (36). Gallocatechin was identified in Litsea glaucescens Kunth through LCMS/MS analysis of its infusion and fermented beverage (37). Catechins are considered to be good antioxidant agents, and it was proved in the study of bark extracts of Quercus sideroxyla Humb. \& Bonpl. (38).
Table 2. List of compounds tentatively identified by LCMS/MS analysis

\begin{tabular}{cllll}
\hline $\begin{array}{c}\text { Sl. } \\
\text { No }\end{array}$ & $\mathbf{m} / \mathbf{z}$ [M-H] & MS/MS & $\begin{array}{l}\text { Tentative } \\
\text { identification }\end{array}$ \\
\hline 1 & 305.0391 & $\begin{array}{l}131.06, \quad 199.13,201.1, \\
215.1,245.08\end{array}$ & Gallocatechin \\
\hline 2 & 223.0339 & $135.12,149,179.1,223.07$ & Sinapic acid \\
\hline 3 & 255.246 & $106.58,117,125,255.24$ & Pinocembrin \\
\hline 4 & 165.0314 & $119.0626,121.04,122.04$ & Paeonol \\
\hline 5 & 161.0569 & $117.06,161.0575$ & Umbelliferone \\
\hline
\end{tabular}
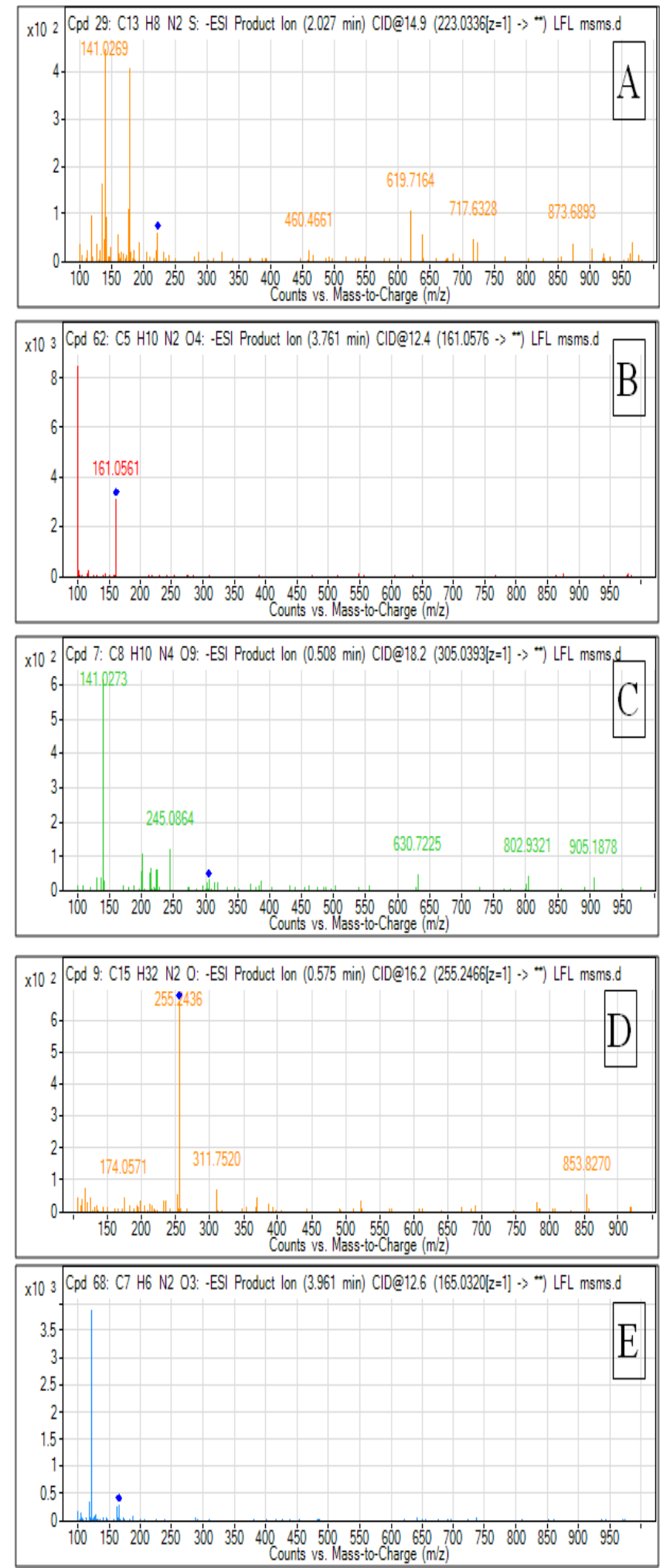

Fig. 3. LCMS spectrum indicated the presence of (A) Sinapic acid, (B) Umbelliferone, (C) Gallocatechin, (D) Pinocembrin, (E) Paeonol. 
Mass fragments of $\mathrm{m} / \mathrm{z}$ value 223.034 [M-H] $^{-}$can be identified as sinapic acid (39) by referring to the LCMS studies on phenolics of red wine (40) and fruits of Melicoccus bijugatus Jacq. (41). Sinapic acid is a polyphenol compound coming under the class phenolic acids and subclass hydrocinnamic acid and reported as an antioxidant, anti-inflammatory, antimicrobial and antianxiety agent prevalent in medicinal plants (42). The presence of sinapic acid was noted in methanol extract of fruits of Litsea cubeba (Lour.) Pers., which is effective against free radicals, DNA damage and toxicities (43).

Flavonol pinocembrin, a member of class flavonoids of polyphenols, was tentatively identified in PLE with mass value 255 [M-H $^{-}$(Pinocembrin mass spectrum) (44). MS/MS analysis of propolis (natural resin) also identified pinocembrin with the same $\mathrm{m} / \mathrm{z}$ value (45), and HPLC-PDA-ESI-MS analysis of three Nolana species displayed its [M-H] $]^{-}$as 255 and revealed its antioxidant activity (46). Pinocembrin and pinocembrin chalcone were isolated and identified from leaves of $L$. fruticosa (Hemsl.) (47). The ion with $165[\mathrm{M}-\mathrm{H}]^{-}$was identified as paeonol, a polyphenol compound and fragments were identified with European MassBank (48). MS analysis of the dried root of Paeoniae suffruticosa Andr. (49) and an anti-Parkinson botanical drug DA9805 confirmed the $\mathrm{m} / \mathrm{z}$ value of paeonol (50). Commercially obtained paeonol was proved as an anti-inflammatory, antioxidant and anti-apoptotic agent in rats (51). The ion with $[\mathrm{M}-\mathrm{H}]^{-} 161$ was identified as umbelliferone (7- hydroxyl coumarin) using the mass bank (52). MS/MS analysis of extracted phenolic compounds of fruits of Rhus coriaria (L.) Sumac reported the presence of umbelliferone with $[\mathrm{M}-\mathrm{H}]^{-} 161$ (53) and roots and stem bark of Aegle marmelos Correa. obtained a mass value of $[\mathrm{M}+\mathrm{H}]^{+}$as 163 (54). Umbelliferone was isolated from the rhizome of Potentilla evestita L. and evaluated its anti-inflammatory and antinociceptive properties in animals (55). Hence, the tentatively identified polyphenolic compounds in the present study are efficient biomolecules with antioxidant, antiinflammatory, anti-apoptotic, antinociceptive, antimicrobial and antianxiety activities and can be considered the contributing factor for the traditional use of $L$. quinqueflora leaves.

\section{Anti-inflammatory assay: Inhibition of protein denaturation}

Polyphenol portion of leaf extract showed inhibition against protein denaturation, a well-documented process during inflammation. The isolated phenolic portion (PLE) showed an increase in inhibitory percentage with an increase in concentration and was statistically significant at $0.1 \%$ level $(p<0.001)$ (Table 3). It inhibited protein denaturation with an IC $_{50}$ value of $23.59 \mu \mathrm{g} / \mathrm{ml}$, almost near the standard drug diclofenac.

Denaturation of proteins can be induced due to different stimuli such as heat, acid, alkali, detergents, alcohol etc. (56). In the present investigation, heat was used as a stimulus. Denatured protein can act as an antigen, affect our system's immunity, and lead to chronic inflammatory conditions like rheumatoid arthritis (57) and amyloidosis (58). Recent studies in ethanolic fraction of fruits of Spondias mangiferra
Willd. and aqueous extract of bark of Ficus benghalensis $\mathrm{L}$. reported protein denaturation under in vitro conditions $(59,60)$. Denaturation of proteins is as a serious cause of rheumatoid arthritis and other inflammatory conditions and their activity against protein denaturation considered them as

Table 3. Percentage of inhibition of protein denaturation by polyphenol fraction (PLE) of Litsea quinqueflora

\begin{tabular}{lll}
\hline Concentration & PLE & DS \\
\hline 62.5 & $48.58 \pm 1.44^{* * *}$ & $39.18 \pm 1.54^{* * *}$ \\
\hline 125 & $60.36 \pm 1.49^{* * *}$ & $74.02 \pm 1.19^{* * *}$ \\
\hline 250 & $77.59 \pm 1.55^{* * *}$ & $83.48 \pm 1.35^{* * *}$ \\
\hline 500 & $90.2 \pm 1.14^{* * *}$ & $93.83 \pm 1.63^{* * *}$ \\
\hline
\end{tabular}

$* * * \mathrm{P} \leq 0.001$. Values represent mean \pm standard deviation of triplicate experiments.

anti-arthritic drugs. Hence, a drug with antidenaturant activity can be considered an antiinflammatory agent. Many plant extracts exhibit antidenaturant activity, where polyphenols, especially flavonoids, are mainly considered as antiinflammatory agents (61). Anti-inflammatory study of a polyphenol-rich extract of Petroselinum crispum (Mill.) Fuss, Apium graveolens L. and Coriandrum sativum L. showed $50 \%$ inhibition of protein denaturation at 118, 227 and $247 \mu \mathrm{g} / \mathrm{ml}$ concentrations, respectively (62). Comparing those $\mathrm{IC}_{50}$ values with PLE depicted the better efficacy of polyphenolic fraction of leaf extract of $L$. quinqueflora as an anti-inflammatory agent. The inhibitory potential of PLE in protein denaturation assay was noticeably higher than that of sequentially isolated leaf extracts (63) and silver nanoparticles capped with methanolic extract (64) of $L$. quinqueflora. So, polyphenols can be considered as more potent phytoconstituent of $L$. quinqueflora. Phenolic compounds are demonstrated as thermal stability enhancers of proteins. Protein-phenol interaction enabled proteins to withstand heatinduced denaturation for a certain time (65). This corroborated the anti-denaturation activity of PLE, especially the polyphenol compounds present in PLE and thus the anti-inflammatory activity.

\section{Antioxidant properties}

Polyphenol portion of PLE exhibited effective radical scavenging activity against free radicals. The $\mathrm{IC}_{50}$ value in the DPPH assay was $122.98 \mu \mathrm{g} / \mathrm{ml}$, and the ABTS assay was $135.44 \mu \mathrm{g} / \mathrm{ml}$. The gradient of radical scavenging activity is proportional to the increase in concentration. The inhibitory percentages obtained with different concentrations of DPPH (Fig. 4) and ABTS (Fig. 5) were statistically significant at $0.1 \%$ level $(\mathrm{p}<0.001)$ (represented with asterisks).

The plant extracts with polyphenol contents exhibit good radical scavenging activities. The polyphenolic extracts of leaves of Ichnocarpus frutescens (L.) R.Br. inhibited free radicals at $\mathrm{IC}_{50}$ value of $163.38 \mu \mathrm{g} / \mathrm{ml} \mathrm{(66),} \mathrm{and} \mathrm{polyphenol-rich}$ extract of fruits of Mallotus philippensis (Lam.) Müll.Arg. showed effective scavenging activity against ABTS and DPPH radicals (67). The radical scavenging activity of PLE was found to be higher than these earlier reports on other plants. Bark and leaf extracts of Litsea glutinosa (Lour.) Robinson, 
Litsea monopetala (Roxb.) Persoon, L. assamica Hook. f. and L. laeta (Nees) Hook. f. reported the

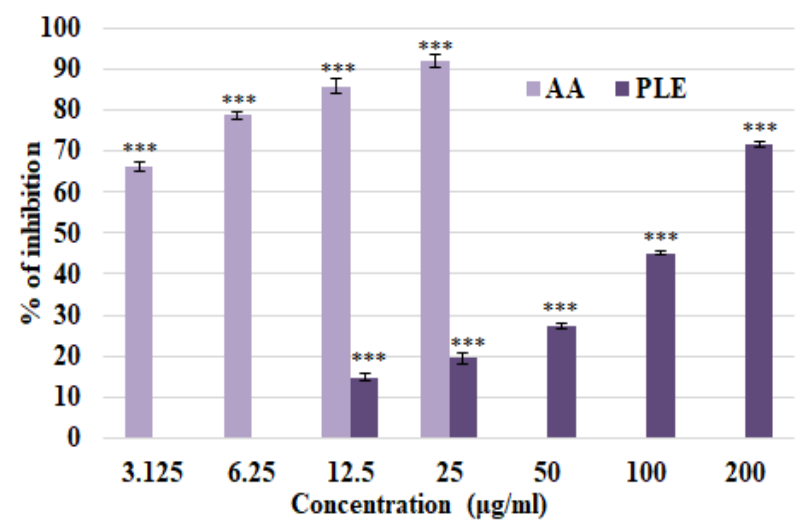

Fig. 4. Percentage of inhibition of ascorbic acid (AA) and polyphenol fraction of leaves of $L$. quinqueflora against DPPH with values represent mean \pm standard deviation of triplicate experiments. ${ }^{* * *} \mathrm{p} \leq 0.001$.

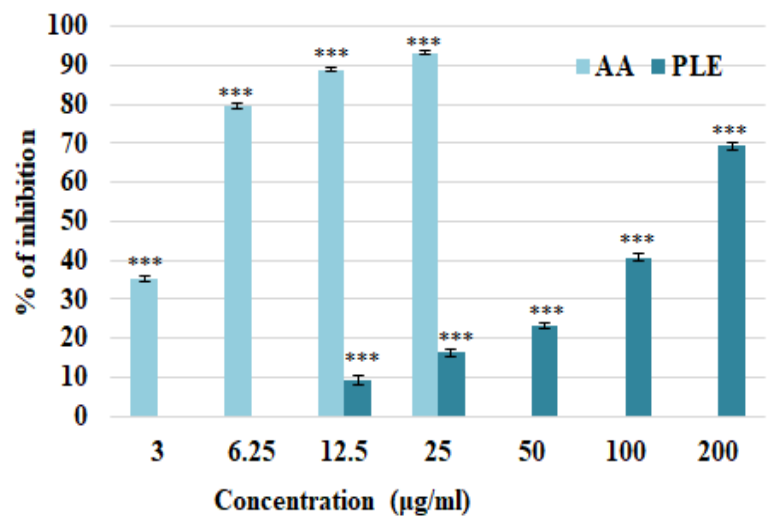

Fig. 5. Percentage of inhibition of ascorbic acid (AA) and polyphenol fraction of leaves of $L$. quinqueflora against ABTS with values represent mean \pm standard deviation of triplicate experiments. ${ }^{* * *} \mathrm{p} \leq 0.001$.

antioxidant activity, especially the scavenging activity against DPPH free radical (68). Based on $\mathrm{IC}_{50}$ value, the antioxidant activity of the polyphenol fraction of $L$. quinqueflora was higher than that of these four species. When compared with the free radical scavenging activities of root extract of Litsea martabanica (Kurz) Hook.f. and stem bark extracts of Litsea petiolata Hook.f. (69,70), PLE exhibited less inhibitory activity against free radicals. Polyphenol compounds isolated from leaves of $L$. quinqueflora can be considered as a potential natural antioxidant source. The hydroxyl groups present in the phenolic constituents of plant extract assumed to be the active centre behind the radical scavenging activity.

\section{Conclusion}

Hydro-alcoholic extract of $L$. quinqueflora (Dennst.) Suresh leaves yielded polyphenols in the form of aglycones. They exhibited higher anti-inflammatory and antioxidant activities than that of crude extracts, as evidenced by previous publications. The compounds present in the polyphenol fraction were tentatively identified as gallocatechin, sinapic acid, pinocembrin, paeonol and umbelliferone and are known for their anti-inflammatory property.
Polyphenol extract of $L$. quinqueflora exhibited antiinflammatory and antioxidant properties in protein denaturation and free radical scavenging assays, respectively and the results were statistically significant. This provides strong support for its dosedependent inhibitory activity. Hence, the present investigation can be assumed as preliminary scientific evidence for the traditional use of Litsea quinqueflora leaves as an anti-inflammatory drug.

\section{Acknowledgements}

The first author gratefully acknowledges Mahatma Gandhi University, Kottayam, Kerala, for Junior Research Fellowship and the technical support given by Dr. Sulaiman C.T, Senior Scientist, Phytochemistry Division, Centre for Medicinal Plants Research, Arya Vaidya Sala, Kottakkal, Kerala, India, for LC/MS analysis.

\section{Authors' contributions}

AM designed the experiment and corrected the manuscript. SM carried out the research and analysis part. Both authors read and approved the final manuscript.

\section{Conflict of interests}

The authors report no conflicts of interest.

\section{References}

1. Abbas M, Saeed F, Anjum FM, Afzaal M, Tufail T, Bashir MS Ishtiaq A, Hussain S, Suleria HA. Natural polyphenols: An overview. Int J Food Prop. 2017;20(8):1689-99.

2. Duthie GG, Gardner PT, Kyle JA. Plant polyphenols: are they the new magic bullet?. Proceedings of the Nutrition Society 2003;62(3):599-03.

3. Cory H, Passarelli S, Szeto J, Tamez M, Mattei J. The role of polyphenols in human health and food systems: A minireview. Front Nutr. 2018;5:87.

4. Yahfoufi N, Alsadi N, Jambi M, Matar C. The immunomodulatory and anti-inflammatory role of polyphenols. Nutr. 2018;10(11):1618-41.

5. Ambriz-Pérez DL, Leyva-López N, Gutierrez-Grijalva EP, Heredia JB. Phenolic compounds: Natural alternative in inflammation treatment. A Review. Cogent Food Agric. 2016;2(1):1131412.

https://doi.org/10.1080/23311932.2015.1131412

6. Wang YS, Wen ZQ, Li BT, Zhang HB, Yang JH. Ethnobotany, phytochemistry and pharmacology of the genus Litsea: An update. J Ethnopharmacol. 2016;181:66-107. https://doi.org/10.1016/j.jep.2016.01.032

7. Kong DG, Zhao Y, Li GH, Chen BJ, Wang XN, Zhou HL, Lou HX, Ren DM, Shen T. The genus Litsea in traditional Chinese medicine: an ethnomedical, phytochemical and pharmacological review. J Ethnopharmacol. 2015;164:256-64. https://doi.org/10.1016/j.jep.2015.02.020

8. Kamle M, Mahato DK, Lee KE, Bajpai VK, Gajurel PR, Gu KS Kumar P. Ethnopharmacological properties and medicinal uses of Litsea cubeba. Plants. 2019;8(6):150. https://doi.org/10.3390/plants8060150

9. Liu R, Zhang HC, Zhou F, Wang RM, Tu Q, Wang JY. Flavonoids and alkaloids from the leaves of Litsea fruticosa. Biochem Syst Ecol. 2013;50:293-95. https://doi.org/10.1016/j.bse.2013.04.008

10. Anilkumar M, Johny J. Evaluation of in vitro anti-Inflammatory activity of the methanolic extract of Litsea quinqueflora (Dennst.) Suresh. J Pharm Biol Sci. 2015;10(2):32-36.

11. Jose SM, Anilkumar M. In vitro antioxidant activity of Litsea quinqueflora (Dennst.) Suresh. J Pharmacogn Phytochem. 2018;7(4):3217-21. 
12. Rodríguez De Luna SL, Ramírez-Garza RE, Serna Saldívar SO. Environmentally friendly methods for flavonoid extraction from plant material: Impact of their operating conditions on yield and antioxidant properties. Sci World J. 2020. https://doi.org/10.1155/2020/6792069

13. Czemplik M, Korzun-Chłopicka U, Szatkowski M, Działo M, Szopa J, Kulma A. Optimization of phenolic compounds extraction from flax shives and their effect on human fibroblasts. Evid-Based Compl Alt Med. 2017. https://doi.org/10.1155/2017/3526392

14. Yassine EZ, Dalila B, Latifa EM, Smahan B, Lebtar S, Sanae A Abdellah F. Phytochemical screening, anti-inflammatory activity and acute toxicity of hydro-ethanolic, flavonoid, tannin and mucilage extracts of Lavandula stoechas L. from Morocco. Int J Pharm Phytochem Res. 2016;8(1):31-37.

15. Lee Y, Howard LR, Villalon B. Flavonoids and antioxidant activity of fresh pepper (Capsicum annuum) cultivars. J Food Sci. 1995;60(3):473-76.

16. Thangaraj P. Detection of phenolic and flavonoid compounds using high performance thin layer chromatography (HPTLC). In: Pharmacological Assays of Plant-Based Natural Products 2016 (pp. 173-75). Springer, Cham.

17. Srivasthava MM. (Ed.) HPTLC: High Performance thin- layer chromatography, (2011) Heidelberg, Dordrecht, London, New York: Springer. https://doi.org/10.1007/978-3-642-14025-9_1

18. Sulaiman CT, Deepak M, Balachandran I. Spectrophotometric and tandem mass spectroscopic analysis of Indian borage (Plectranthus amboinicus (Lour.) Spreng.) for its polyphenolics characterisation. Beni-Suef Univ J Basic Appl Sci. 2018;7(4):47173.

19. Mizushima Y, Kobayashi M. Interaction of anti-inflammatory drugs with serum proteins, especially with some biologically active proteins. J Pharm Pharmacol. 1968;20(3):169-73. https://doi.org/10.1111/j.2042-7158.1968.tb09718.x

20. Kiranmayi GV. Preliminary phytochemical screening and in vitro evaluation of anti-inflammatory, anti-arthritic and thrombolytic activities of ethanolic leaf extract of Bauhinia purpurea. Int J Green Pharm. 2018;12(01). http://dx.doi.org/10.22377/ijgp.v12i01.1627

21. Brand-Williams W, Cuvelier ME, Berset CL. Use of a free radical method to evaluate antioxidant activity. LWT Food Sci Technol. 1995;28(1):25-30. https://doi.org/10.1016/S00236438(95)80008-5

22. Re R, Pellegrini N, Proteggente A, Pannala A, Yang M, RiceEvans C. Antioxidant activity applying an improved ABTS radical cation decolorisation assay. Free Radical Biol Med. 1999;26(9-10):1231-37. 5849(98)00315-3

23. Shunmugaperumal T, Kaur V. In vitro anti-inflammatory and antimicrobial activities of azithromycin after loaded in chitosan-and tween 20-based oil-in-water macroemulsion for acne management. Aaps Pharm Sci Tech. 2016;17(3):700-09. https://doi.org/10.1208/s12249-015-0401-2

24. Osman NI, Sidik NJ, Awal A, Adam NA, Rezali NI. In vitro xanthine oxidase and albumin denaturation inhibition assay of Barringtonia racemosa L. and total phenolic content analysis for potential anti-inflammatory use in gouty arthritis. Journal of Intercultural Ethnopharmacology. 2016;5(4):343-49. https://doi.org/10.5455/jice.20160731025522

25. Khoddami A, Wilkes MA, Roberts TH. Techniques for analysis of plant phenolic compounds. Mol. 2013;18(2):2328-75. https://doi.org/10.3390/molecules18022328

26. Hu J, Zhao Y, Ma C, Wang W, Xing D, Du L. Acid hydrolytic method for determination of Ginkgo biloba total flavonoids in rat plasma by HPLC for pharmacokinetic studies. Tsinghua Sci Technol. 2010;15(4):452-59. https://doi.org/10.1016/S10070214(10)70087-0

27. Alara OR, Abdurahman NH, Ukaegbu CI. Extraction of phenolic compounds: a review. Curr Res Food Sci. 2021;4:200-14. https://doi.org/10.1016/j.crfs.2021.03.011

28. Wang Q, Ge X, Tian X, Zhang Y, Zhang J, Zhang P. Soy isoflavone: The multipurpose phytochemical. Biomed Rep. 2013;1(5):697-701. https://doi.org/10.3892/br.2013.129

29. Kaur H, Kaur G. A critical appraisal of solubility enhancement techniques of polyphenols. J Pharm. 2014;1-14. https://doi.org/10.1155/2014/180845
30. Kuruvilla J, Iyer RS, Anilkumar M. Phytochemical evaluation and HPTLC fingerprint profile of Cissus latifolia Lam. Stem. Int J Pharm Sci Res. 2019;10(2):568-77.

31. Srivastava B, Sharma VC, Verma SC, Singh R, Jadhav AD. Plant part substitution in Litsea chinensis for medicinal use: A comparative phytochemical approach. Anc Sci Life. 2017; 37(2):57. https://doi.org/10.4103/asl.ASL_168_16

32. Senguttuvan J, Subramaniam P. HPTLC Fingerprints of Various Secondary Metabolites in the Traditional Medicinal Herb Hypochaeris radicata L. J Bot. 2016;1-11. https://doi.org/10.1155/2016/5429625

33. Gwatidzo L, Dzomba P, Mangena M. TLC separation and antioxidant activity of flavonoids from Carissa bispinosa, Ficus sycomorus and Grewia bicolar fruits. Nutrire. 2018;43(1):1-7. https://doi.org/10.1186/s41110-018-0062-5

34. Pontis JA, Costa LA, Silva SJ, Flach A. Color, phenolic and flavonoid content, and antioxidant activity of honey from Roraima, Brazil. Food Sci Technol. 2014;34(1):69-73. https://doi.org/10.1590/S0101-20612014005000015

35. MassBank; an ecosystem of databases and tools for mass spectrometry reference spectra. Gallocatehin. https://massbank.eu/MassBank/RecordDisplay?id=BS003902

36. Hossain MB, Rai DK, Brunton NP, Martin-Diana AB, Barry-Ryan C. Characterization of phenolic composition in Lamiaceae spices by LC-ESI-MS/MS. J Agric Food Chem. 2010; 58(19):10576-81. https://doi.org/10.1021/jf102042g

37. Gamboa-Gómez CI, González-Laredo RF, Gallegos-Infante JA, Pérez M, Moreno-Jiménez MR, Flores-Rueda AG, RochaGuzmán NE. Antioxidant and angiotensin-converting enzyme inhibitory activity of Eucalyptus camaldulensis and Litsea glaucescens infusions fermented with kombucha consortium. Food Technol Biotechnol. 2016;54(3):367-74. https://doi.org/10.17113/ftb.54.03.16.4622

38. Rosales-Castro M, González-Laredo RF, Rocha-Guzmán NE Gallegos-Infante JA, Rivas-Arreola MJ, Karchesy JJ. Antioxidant activity of fractions from Ouercus sideroxyla bark and identification of proanthocyanidins by HPLC-DAD and HPLC MS. Holzforschung. 2012;66(5):577-84.

39. MassBank; an ecosystem of databases and tools for mass spectrometry reference spectra. Sinapic acid https://massbank.eu/MassBank/RecordDisplay?id=PR307086

40. Sun J, Liang F, Bin Y, Li P, Duan C. Screening non-colored phenolics in red wines using liquid chromatography/ultraviolet and mass spectrometry/mass spectrometry libraries. Mol. 2007;12(3):679-93. https://doi.org/10.3390/12030679

41. Bystrom LM, Lewis BA, Brown DL, Rodriguez E, Obendorf RL. Characterisation of phenolics by LC-UV/Vis, LC-MS/MS and sugars by GC in Melicoccus bijugatus Jacq. 'Montgomery' fruits. Food Chem. 2008;111(4):1017-24 https://doi.org/10.1016/j.foodchem.2008.04.058

42. Nićiforović N, Abramovič H. Sinapic acid and its derivatives: natural sources and bioactivity. Compr Rev Food Sci Food Safe. 2014;13(1):34-51. https://doi.org/10.1111/1541-4337.12041

43. Seal T, Chaudhuri K, Pillai B, Chakrabarti S, Mondal T, Auddy B. Evaluation of antioxidant activities, toxicity studies and the DNA damage protective effect of various solvent extracts of Litsea cubeba fruits. Heliyon. 2020;6(3):e03637. https://doi.org/10.1016/j.heliyon.2020.e03637

44. MassBank; an ecosystem of databases and tools for mass spectrometry reference spectra. Pinocembrin. https://massbank.eu/MassBank/RecordDisplay.jsp? id=BML00902

45. Sawaya AC, Tomazela DM, Cunha IB, Bankova VS, Marcucci MC, Custodio AR, Eberlin MN. Electrospray ionisation mass spectrometry fingerprinting of propolis. Anal. 2004;129(8):73944. https://doi.org/10.1039/B403873H

46. Simirgiotis MJ, Benites J, Areche C, Sepúlveda B. Antioxidant capacities and analysis of phenolic compounds in three endemic Nolana species by HPLC-PDA-ESI-MS. Mol. 2015; 20(6):11490-507. https://doi.org/10.3390/molecules200611490

47. Liu R, Zhang HC, Zhou F, Wang RM, Tu Q, Wang JY. Flavonoids and alkaloids from the leaves of Litsea fruticosa. Biochem Syst Ecol. 2013;50:293-95. https://doi.org/10.1016/j.bse.2013.04.008

48. MassBank; an ecosystem of databases and tools for mass spectrometry reference spectra. Paeonol. https://massbank.eu/MassBank/RecordDisplay?id=PR303539 
49. Zhao X, Sun Y. Analysis of Paeoniae radix by high-performance liquid chromatography-electrospray ionisation-mass $\begin{array}{llll}\text { spectrometry. } & \text { Anal } & \text { Sci. } & \text { 2003;19(9):1313-15. }\end{array}$ https://doi.org/10.2116/analsci.19.1313

50. Kwon MH, Jeong JS, Ryu J, Cho YW, Kang HE. Simultaneous determination of saikosaponin a, paeonol and imperatorin, components of DA-9805, in rat plasma by LC-MS/MS and application to a pharmacokinetic study. J Chromatogr B. 2017; 1068:289-96. https://doi.org/10.1016/j.jchromb.2017.10.059

51. Gong X, Yang Y, Huang L, Zhang Q, Wan RZ, Zhang P, Zhang B. Antioxidation, anti-inflammation and anti-apoptosis by paeonol in LPS/d-GalN-induced acute liver failure in mice. Int Immunopharmacol.

2017;46:124-32 https://doi.org/10.1016/j.intimp.2017.03.003

52. MassBank; an ecosystem of databases and tools for mass spectrometry reference spectra. Umbelliferone. https://massbank.eu/MassBank/RecordDisplay?id=FIO00499

53. Abu-Reidah IM, Ali-Shtayeh MS, Jamous RM, Arráez-Román D, Segura-Carretero A. HPLC-DAD-ESI-MS/MS screening of bioactive components from Rhus coriaria L. (Sumac) fruits. Food Chem. https://doi.org/10.1016/j.foodchem.2014.06.011

54. Gajbhiye NA, Makasana J, Dhanani T, Saravanan R. Development and validation of LC-ESI-MS/MS method for simultaneous determination of four coumarin derivatives and an alkaloid from root and stem bark of Aegle marmelos Correa. $\begin{array}{lll}\text { Acta } & \text { Chromatographica. } & \text { 2016;28(4):473-88. }\end{array}$ https://doi.org/10.1556/1326.2016.28.4.6

55. Rauf $\mathrm{A}$, Khan $\mathrm{R}$, Khan $\mathrm{H}$, Pervez $\mathrm{S}$, Pirzada AS. In vivo antinociceptive and anti-inflammatory activities of umbelliferone isolated from Potentilla evestita. Nat Prod Res. 2014;28(17):1371-74.

https://doi.org/10.1080/14786419.2014.901317

56. Sangeetha G, Vidhya R. In vitro anti-inflammatory activity of different parts of Pedalium murex (L.). Int J Herb Med. 2016; 4(3):31-36.

57. Malarkani K, Sarkar I, Selvam S. Denaturation studies on bovine serum albumin-bile salt system: bile salt stabilises bovine serum albumin through hydrophobicity. J Pharmaceut Anal. 2018;8(1):27-36 https://doi.org/10.1016/j.jpha.2017.06.007

58. Elisha IL, Dzoyem JP, McGaw LJ, Botha FS, Eloff JN. The antiarthritic, anti-inflammatory, antioxidant activity and relationships with total phenolics and total flavonoids of nine South African plants used traditionally to treat arthritis. BMC Compl Altern Ned. 2016;16(1):1-10 https://doi.org/10.1186/s12906-016-1301-z

59. Khalid M, Alqarni MH, Shoaib A, Arif M, Foudah AI, Afzal O, Ali A, Ali A, Alqahtani SS, Altamimi AS. Anti-Arthritic and antiinflammatory potential of Spondias mangifera extract fractions: an in silico, in vitro and in vivo approach. Plants. 2021;10(5):825. https://doi.org/10.3390/plants10050825

60. Joshi DG, Jat RK, Patil SB. In vitro protein denaturation and membrane stabilising anti-arthritic activity of aqueous extracts of bark of Ficus benghalensis L. against methotrexate. The Pharma Innovation Journal. 2021;10(4):689-92.

61. Marrassini C, Peralta I, Anesini C. Comparative study of the polyphenol content-related anti-inflammatory and antioxidant activities of two Urera aurantiaca specimens from different geographical areas. Chinese Med. 2018;13(1):1-2. https://doi.org/10.1186/s13020-018-0181-1

62. Derouich M, Bouhlali ED, Hmidani A, Bammou M, Bourkhis B, Sellam K, Alem C. Assessment of total polyphenols, flavonoids and anti-inflammatory potential of three Apiaceae species grown in the Southeast of Morocco. Sci Afr. 2020;9:e00507. https://doi.org/10.1016/j.sciaf.2020.e00507

63. Jose SM, Anilkumar M. In vitro anti inflammatory studies of the leaf extracts of Litsea quinqueflora (Dennst.) Suresh Biosci Biotechnol Res Commun. 2020;13(4):2022-28. http://dx.doi.org/10.21786/bbrc/13.4/58

64. Jose SM, Anilkumar M. Antibacterial and anti-inflammatory activity of the silver nano particles synthesised from the methanolic leaf extract of Litsea quinqueflora (Dennst.) Suresh Adv Sci Eng Med. 2020;12(4):443-49. https://doi.org/10.1166/asem.2020.2551

65. Ozdal T, Capanoglu E, Altay F. A review on protein-phenolic interactions and associated changes. Food Res Int 2013;51(2):954-70. https://doi.org/10.1016/j.foodres.2013.02.009

66. Kumarappan CT, Thilagam E, Mandal SC. Antioxidant activity of polyphenolic extracts of Ichnocarpus frutescens. Saudi J Biol Sci. 2012;19(3):349-55. https://doi.org/10.1016/j.sjbs.2012.04.004

67. Gangwar M, Gautam MK, Sharma AK, Tripathi YB, Goel RK Nath G. Antioxidant capacity and radical scavenging effect of polyphenol rich Mallotus philippenensis fruit extract on human erythrocytes: an in vitro study. Sci World J. 2014 https://doi.org/10.1155/2014/279451

68. Choudhury D, Ghosal M, Das AP, Mandal P. In vitro antioxidant activity of methanolic leaves and barks extracts of four Litsea plants. Asian J Plant Sci Res. 2013;3:99-107.

69. Kunnaja P, Chansakaow S, Wittayapraparat A, Yusuk P, Sireeratawong S. In vitro antioxidant activity of Litsed martabanica root extract and its hepatoprotective effect on chlorpyrifos-induced toxicity in rats. Mol. 2021;26(7):1906. https://doi.org/10.3390/molecules26071906

70. Ambarwati NS, Elya B, Mahayasih PG, Awang MS, Omar H. Antioxidant activity of Litsea petiolata Hk. f. In Journal of Physics: Conference Series 2021;1869(1);012055. IOP Publishing. https://doi.org/10.1088/1742-6596/1869/1/012055

\section{Additional information}

Peer review information: Plant Science Today thanks Sectional Editor and the other anonymous reviewers for their contribution to the peer review of this work.

Reprints and permissions information is available at https://horizonepublishing.com/journals/index.php/PST/open_access_policy

Publisher's Note: Horizon e-Publishing Group remains neutral with regard to jurisdictional claims in published maps and institutional affiliations.

To cite this article: Jose S M, Anilkumar M LCMS/MS analysis and evaluation of anti-inflammatory and antioxidant activities of the polyphenol fraction of Litsea quinqueflora (Dennst.) Suresh. Plant Science Today. 2021;8(4):865-872. https://doi.org/10.14719/pst.2021.8.4.1243

Plant Science Today, published by Horizon e-Publishing Group, is covered by Scopus, Web of Science, BIOSIS Previews, Clarivate Analytics, etc. See https://horizonepublishing.com/journals/index.php/PST/indexing_abstracting 